\section{KẾT LUẬN}

1. Tỷ lệ diệt trừ $\mathrm{H}$. pylori lần đầu bằng phác đồ bốn thuốc chứa bismuth theo ý định điều trị (ITT) và thiết kế nghiên cứu (PP) tương ứng là $86,6 \%$ và $93,2 \%$. Tỷ lệ diệt trừ $H$. pylori lần hai bằng phác đồ bốn thuốc chứa bismuth theo ý định điều trị (ITT) và thiết kế nghiên cứu (PP) tương ứng là $87,3 \%$ và $89,9 \%$

2. Tác dụng không mong muốn khi sử dụng phác đồ bốn thuốc chứa bismuth lần đầu và lần thứ hai tương ứng là: $66,9 \%$ và $58,5 \%$. Các tác dụng không mong muốn hay gặp ở hai nhóm gồm: phân màu đen, mệt mỏi, vị kim loại...Tuy nhiên, phần lớn đều nhẹ và bình phục sau 01 tuần dùng thuốc

\section{TÀI LIÊU THAM KHẢO}

1. Bùi Č́ní Nam, Nguyển Thị Cẩm Tú, Phạm Thị Thu Hương và cs. Hiệu quả diệt trừ Helicobacter pylori bằng phác đồ PCA, PTMB, PLA. Tap chí khoa học Tiêu hóa Việt Nam 2016;IX(45): 2851-2854.

2. Đặng Ngọc Qứ Huế, Trấn Văn Huy, Nguyễn Thanh Hải. Viêm dạ dày mạn do Helicobacter pylori: Hiệu quả diệt trừ của phác đồ bốn thuốc chứa bismuth (EBMT). Tap chí khoa học Tiêu hóa Việt Nam 2016; IX(45): 2862-2871.

3. Nguyê̂n Thị Nhã Đoan. Hiêu quả của levofloxacin trong phác đồ bốn thuốc chứa bismth diêt trừ Helicobacter pylori. Tạp chí khoa học Tiêu hóa Việt Nam 2018;IX(53): 3294-3299

4. Tuong TTK. The eradication rate of levofloxacin containing quadruple therapy for the first-line treatment of Helicobacter pylori. Biomedical Journal of Scientific \& Technical Research 2020;27(1): 20494-20496

5. Khúc Thu Trang, Nguyễn Công Long, Vũ Trường Khanh. Hiệu quả của phác đồ bốn thuốc chứa bismuth ở bênh nhân loét hành tá tràng chảy máu có Helicobacter pylori. Tạp chí khoa học Tiêu hóa Việt Nam 2021;IX(6): 3842-384

6. Tuong TTK, Huy HQ, Hong TND, et al. Bismuth quadruple therapy versus levofloxacin triple therapy for first-line Helicobacter pylori eradication treatment: multicenter study. Medical Science 2020;24(104): 2246-2250

7. Trân Thiện Trung, Phạm Văn Tấn, Quách Trọng Đức và cs. Hiệu quả của phác đô EAL và EBMT trong diêt trừ Helicobacter pylori điều trị thất bai lần đâu. Ý học TP Hồ Chí Minh 2009;13(phụ bản số 1): 11-17

8. Nguyễn Thúy Vinh. Đánh giá hiệu quả diệt trừ Helicobacter pylori lần hai bằng phác đô $E A C$ và $d$ EBMT. Tap chí y học thực hành 2011;4: 23-26

9. Trân Thị Khánh Tường. Hiệu quá của phác đồ bốn thuổc có levofloxacin cho bệnh nhân nhiếm Helicobacter pylori thất bại điêu trị lần đâu với phác đồ ba thuốc chuẩn. Tạp chí Y học Việt Nam 2019;473: 185-190

\title{
TÁC DỤNG KHÔNG MONG MUỐN CỦA ĐIỀU TRI BƯớC MộT PHÁC Đồ PACLITAXEL - CARBOPLATIN UNG THƯ PHỔI KHÔNG TẾ BÀO NHỎ GIAI ĐOẠN IV Ở' BỆNH NHÂN CAO TUỔI
}

\section{TÓM TẮT}

Mục tiêu: Đánh giá các tác dụng không mong muốn của điều trị bước một phác đồ Paclitaxel Carboplatin ung thư phổi không tế bào nhỏ giai đoạn IV ở bệnh nhân cao tuổi tại Bệnh viện Hữu Nghị. Đối tượng và phương pháp nghiên cứu: Nghiên cứu mô tả, phối hợp hồi cứu và tiến cứu 51 bệnh nhân $\geq$ 60 tuối, ung thư phổi không tế bào nhỏ giai đoạn IV được điều trị hoá chất bước môt phác đồ PaclitaxelCarboplatin tại Bệnh viện Hữu Nghị, từ tháng 01/2016 đến tháng $12 / 2020$. Kểt quả: Tỷ lệ giảm BC, BCTT là $25,5 \% ; 37,3 \%$. Trong đó chủ yêu là giảm $B C$ và giảm BCTT đô $1 / 2$ là $19,6 \%$ và $27,4 \%$. Tỷ lệ giảm HST, giảm tiểu cầu là $29,4 \%$ và $13,7 \%$. Tỷ lệ buôn nôn,

\footnotetext{
${ }^{1}$ Bệnh viện Hữu Nghi

${ }^{2}$ Bệnh viện $K$

Chịu trách nhiệm chính: Trân Đình Quang

Email: dinhquang228@gmail.com

Ngày nhận bài: 3.8.2021

Ngày phản biện khoa học: 4.10.2021

Ngày duyệt bài: 14.10.2021
}

Trần Đình Quang ${ }^{1}$, Nguyễn Thị Thái Hòa ${ }^{2}$

nôn là $19,6 \%$ và 9,8\%. Tiêu chảy chiếm tỷ lệ $11,8 \%$. Tỷ lệ rối loạn thần kinh cảm giác ngoại vi, đau xương khớp là $17,6 \%$ và $21,6 \%$. Kêt luận: Tác dụng không mong muốn của phác đồ chủ yếu ở mức độ $1 / 2$, an toàn để áp dụng điều trị cho bệnh nhân cao tuổi.

Tứ khóa: Paclitaxel-Carboplatin, Ung thư phổi không tế bào nhỏ, cao tuổi

\section{SUMMARY}

\section{SIDE-EFFECTS OF FIRST LINE PACLITAXEL - CARBOPLATIN REGIMEN FOR STAGE IV NON- SMALL CELL LUNG CANCER IN OLDER ADULTS}

Objective: EstimateSide-effects of first line Paclitaxel - Carboplatin regimen for stage IV nonsmall cell lung cancer in elderly patientsat Huu Nghi Hospital. Patients and Methods: Retrospective and prospective estimated side effects of 51 patients older than 60 years with stage IV non-small cell lung cancer receiving Paclitaxel-Carboplatin asfirst line chemotherapyat Huu Nghi Hospital from January 2016 to December 2021. Results: Of our 51 patients, the rate of leukopenia,neutropeniawere $25,5 \%$ and $37,3 \%$ respectively. Leukopenia andneutropenia grade $1 / 2$ 
occurred in $19,6 \%$ and $27,4 \%$. Anaemia and thrombopenia were $29,4 \%$ and $13,7 \%$. The rate of vomitingand nausea were 19,6\% and 9,8\%.Diarrhea occurred in $11,8 \%$. The rate of peripheralneuropathy and osteoarthritis were $17,6 \%$ and $21,6 \%$. Conclusions: Side-effects of the regimen mostly at grade 1 or 2, safely to apply on older adults.

Keywords: Paclitaxel-Carboplatin, Non-small cell lung cancer, Older adults

\section{I. ĐĂT VẤN ĐỀ}

Ung thư phổi (UTP) là bênh lý ác tính thường gặp nhất và là nguyên nhân tử vong hàng đầu do ung thư trên toàn thế giới. Tại Việt Nam, ung thư phổi đứng thứ hai về tỷ lệ mới mắc ở nam và thứ ba ở nữ [4]. UTP được chia làm 2 nhóm chính dựa trên đặc điểm mô bệnh học là ung thư phổi không tế bào nhỏ (UTPKTBN) và ung thư phổi tế bào nhỏ, trong đó UTPKTBN chiếm khoảng $80-85 \%$. Tai thời điểm chẩn đoán có khoảng 2/3 số bệnh nhân UTPKTBN đã ở giai đoạn tiến xa hoặc di căn, trong đó có hơn $50 \%$ bệnh nhân trên 60 tuổi[1]. Phác đồ hóa trị phối hợp bộ đôi cónhóm platinum được coi là điêu trị chuẩn bước một UTPKTBN giai đoạn tiến xa hoặc di căn. Trong đó, phác đồ Paclitaxel-Carboplatin đã được chứng minh có hiệu quả và an toàn với những bệnh nhân cao tuổi qua nhiều thử nghiệm lâm sàng[7]. Tại Bệnh Viện Hữu Nghị với đặc điểm chủ yếu là bệnh nhẩn cao tuổi, phác đồ Paclitaxel-Carboplatin đã được sử dụng rộng rãi trong điêu trị bước một UTPKTBN giai đoạn IV. Tuy nhiên, chưa có nghiên cứu nàođánh giá tác dụng không mong muốn của phác đồ này đối với nhóm bệnh nhân cao tuổi tại đây. Do vậy, chúng tôi tiến hành nghiên cứu này với mụctiêu:Đánh giá các tác dụng không mong muốn của điều trị bước một phác đồ Paclitaxel - Carboplatin ung thư phổi không tế bào nhỏ giai đoạn IV ở bệnh nhân cao tuổi tại Bệnh viện Hữu Nghị.

\section{II. ĐỐI TƯỢNG VÀ PHƯƠNG PHÁP NGHIÊN CỨU}

1. Đối tượng nghiên cứu: Các bệnh nhân $\geq 60$ tuổi UTPKTBN giai đoạn IV được điều trị hoá chất bước một phác đồ Paclitaxel Carboplatin tại Bệnh viện Hữu Nghị từ tháng 01/2016 đến tháng 12/2020.

Tiêu chuân lựa chọn:

- UTPKTBN giai đoạn IV (theo phân loại của AJCC năm 2017).

- Được chẩn đoán xác định bằng mô bệnh học.

- Khổng di căn não.

- BN $\geq 60$ tuổi (theo pháp lệnh người cao tuổi Việt Nam sửa đổi năm 2009)

- Chỉ số toàn trạng (PS) từ 0-2.

- Có các tổn thương đích đánh giá đáp ứngđược theo tiêu chuẩn RECIST.

- Chưa được điều trị bằng một phương pháp điều trị ung thư nào trước đó

\section{Phương pháp nghiên cứu}

2.1 Thiết kế nghiên cứu: Nghiên cứu mô tả, phối hợp hồi cứu và tiến cứu.

2.2 Cỡ mẫu nghiên cứu: Chọn mẫu thuận tiện,thu nhận 51 bệnh nhân.

2.3 Trình tự nghiên cứu. Các bệnh nhân được chẩn đoán UTPKTBN giai đoạn IV có đầy đủ các tiêu chuẩn trên được điều trị bước một bằng hóa chất phác đồ Paclitaxel $175 \mathrm{mg} / \mathrm{m} 2$ dangày 1, Carboplatin AUC 5 ngày 1 , chu kỳ 21 ngày, tối thiểu 3 chu kỳ. Sau mồi đợt bệnh nhân được đánh giá lâm sàng, xét nghiệm và ghi nhận độc tính. Các bệnh nhân đánh giá bệnh đáp ứng được điều trị đủ 4-6 chu kỳ.

Đánh giá thể trạng bệnh nhân: Theo thang của Tổ chức $Y$ tế Thế giới

Độc tính điều trị: Theo tiêu chuẩn về độc tính CTCAEv5.0

2.4 Xử trí phân tích số liệu: Số liệu được nhập và xử lý bằng phầnmềm SPSS 20.0

\section{KẾT QUẢ NGHIÊN CỨU}

\section{1. Đặc điểm lâm sàng,cận lâm sàng}

\begin{tabular}{|c|c|c|c|}
\hline \multicolumn{4}{|c|}{,cạn lam } \\
\hline & $\%$ & \multicolumn{2}{|c|}{$\begin{array}{l}\text { घ0 - } 65 \text { tuồi } \\
\text { = } 66 \text { - } 70 \text { tuổi } \\
\text { > } 70 \text { tuổi }\end{array}$} \\
\hline \multicolumn{4}{|c|}{$\begin{array}{l}\text { Biểu đồ 1: Phân loai bênh nhân theo tuổi } \\
\text { Nhận xét: Bệnh nhân trong nghiên cứu chủ } \\
\text { yếu thuộc nhóm tuổi } 60-70 \text { tuối chiếm } 64,7 \% \text {; } \\
\text { nhóm > } 70 \text { tuổi chiếm } 35,3 \% \text {. Bệnh nhân lớn } \\
\text { tuổi nhất } 77 \text { tuổi. } \\
\text { Bảng 1: Đặc điểm lâm sàng, cận lâm sàng }\end{array}$} \\
\hline Đặc điểm & bệnh nhân & $\begin{array}{l}\text { Số bệnh } \\
\text { nhân }(N)\end{array}$ & $\begin{array}{l}\text { Tỷ lề } \\
(\%)\end{array}$ \\
\hline Giới tính & $\begin{array}{c}\text { Nam } \\
\text { Nữ }\end{array}$ & $\begin{array}{c}43 \\
8\end{array}$ & $\begin{array}{l}84,3 \\
15.7\end{array}$ \\
\hline Hút thuốc & $\begin{array}{c}\text { Có } \\
\text { Không }\end{array}$ & $\begin{array}{l}32 \\
19\end{array}$ & $\begin{array}{l}62,7 \\
37,3\end{array}$ \\
\hline Giai đoạn & $\begin{array}{l}\text { IVA } \\
\text { IVB }\end{array}$ & $\begin{array}{l}22 \\
29\end{array}$ & $\begin{array}{l}43,1 \\
56,9\end{array}$ \\
\hline $\begin{array}{l}\text { Mô bệnh } \\
\text { học }\end{array}$ & $\begin{array}{c}\text { UTBM } \\
\text { Tuyến } \\
\text { UTBM Vảy } \\
\text { UTBM Tế } \\
\text { bào lớn }\end{array}$ & $\begin{array}{c}36 \\
14 \\
1\end{array}$ & $\begin{array}{c}70,6 \\
27,4 \\
2,0\end{array}$ \\
\hline
\end{tabular}




\begin{tabular}{|c|c|c|c|}
\hline Bệnh & Có & 19 & 37,3 \\
kèm theo & Không & 32 & 62,7 \\
\hline
\end{tabular}

Nhận xét: - Đa phần bệnh nhân nghiên cứu là nam chiếm $84,3 \%$, nữ chiếm $15,7 \%$.

- Tỷ lệ hút thuốc chiếm $62,7 \%$.

- Giai đoạn IVB chiếm $56,9 \%$, giai đoạn IVA chiếm $43,1 \%$.

- UTBM tuyến chiếm tỷ lê cao nhất 70,6\%, còn lại là UTBM vảy chiếm $27,4 \%$ và UTBM tế bào lớn chiếm 2,0\%.

- Tỷ lệ bệnh nhân có bệnh kèm theo chiếm $37,3 \%$.

\section{Biểu đồ 2: Liều điều trị so với liều chuẩn}

Bảng 2 : Độc tính trên hệ tạo huyêt

\begin{tabular}{|c|c|c|c|c|c|}
\hline \multirow{2}{*}{$\begin{array}{c}\text { Độc tính trến hệ tạo } \\
\text { huyết }\end{array}$} & \multicolumn{5}{|c|}{ Độ độc tính } \\
\cline { 2 - 6 } & Độ 1 N \% & Độ 2 N \% & Độ 3 N \% & Độ 4 N \% & Tống N \% \\
\hline Giảm bạch câuu & $6(11,8)$ & $4(7,8)$ & $3(5,9)$ & $0(0)$ & $13(25,5)$ \\
\hline Giảm bạch cầu trung tính & $9(17,6)$ & $5(9,8)$ & $4(7,8)$ & $1(2,0)$ & $19(37,3)$ \\
\hline Giảm huyết sắc tố & $10(19,6)$ & $5(9,8)$ & $0(0)$ & $0(0)$ & $15(29,4)$ \\
\hline Giảm tiếu cầu & $6(11,8)$ & $1(2,0)$ & $0(0)$ & $0(0)$ & $7(13,7)$ \\
\hline
\end{tabular}

Nhận xét: - Độc tính hệ tạo huyết chủ yếu là độ 1/2.

- Tỷ lệ giảm bạch cầu là $25,5 \%$, giảm bạch cầu độ 3 chỉ có $5,9 \%$, không có độ 4

- Tỷ lể giảm bạch câu trung tính là $37,3 \%$, giảm độ $3 / 4$ chỉ có $9,8 \%$

- Tỷ lể giảm huyết sắc tố và giảm tiểu câu tương ứng là $29,4 \%$ và $13,7 \%$ đều ở độ $1 / 2$.

2.2 Độc tính trên chức năng gan, thận, tiêu hóa

Bảng 3: Độc tính trên chức năng gan, thận, tiêu hóa

\begin{tabular}{|c|c|c|c|c|c|}
\hline Độc tính trên chức năng & \multicolumn{5}{|c|}{ Độ độc tính } \\
\cline { 2 - 6 } gan, thận, tiêu hóa & Độ 1 N \% & Độ 2 N \% & Độ 3 N \% & Độ 4 N \% & Tổng N \% \\
\hline Tăng AST/ALT & $6(11,8)$ & $1(2,0)$ & $0(0)$ & $0(0)$ & $7(13,7)$ \\
\hline Tăng Creatinin & $1(2,0)$ & $0(0)$ & $0(0)$ & $0(0)$ & $1(2,0)$ \\
\hline Buồn nôn & $9(17,6)$ & $1(2,0)$ & $0(0)$ & $0(0)$ & $10(19,6)$ \\
\hline Nôn & $4(7,8 \%)$ & $1(2,0)$ & $0(0)$ & $0(0)$ & $5(9,8 \%)$ \\
\hline Tiêu chảy & $6(11,8)$ & $0(0)$ & $0(0)$ & $0(0)$ & $6(11,8)$ \\
\hline
\end{tabular}

Nhận xét:- Tăng men gan gặp 13,7\% chỉ ở độ $1 / 2$

- Tắng Creatinin chỉ gặp ở 1 BN chiếm 2,0\%.

- Tỷ lệ buồn nôn và nổn tương ứng là $19,6 \%$ và $9,8 \%$ đều ở độ $1 / 2$.

- Tỷ lệ tiêu chảy là $11,8 \%$ đều ở độ 1 .

\subsection{Các đôc tính khác}

\section{Bảng 4: Các độc tính khác}

\begin{tabular}{|c|c|c|c|c|c|}
\hline \multirow{2}{*}{ Độc tính khác } & \multicolumn{4}{|c|}{ Độ độc tính } & \multirow[b]{2}{*}{ Tổng N \% } \\
\hline & Độ 1 N \% & Độ 2 N \% & Độ 3 N \% & Độ 4 N \% & \\
\hline Thần kinh ngoại vi & $7(13,7)$ & $2(3,9)$ & $0(0)$ & $0(0)$ & $9(17,6)$ \\
\hline Đau xương khớp & $9(17,6)$ & $2(3,9)$ & $0(0)$ & $0(0)$ & $11(21,6)$ \\
\hline Rụng tóc & $0(0)$ & $0(0)$ & $21(41,2)$ & $30(58,8)$ & $51(100)$ \\
\hline
\end{tabular}

Nhận xét: - Độc tính thần kinh cảm giác ngoại vi chiếm $17,6 \%$ ở độ $1 / 2$.

- Đau xương khớp chiếm $21,6 \%$ ở độ 1/2.

- Tất cả bệnh nhân đều rụng tóc sau hóa trị, $41,2 \%$ độ 3 và $58,8 \%$ độ 4 .

2.4 Độc tính gây trì hoãn và ngưng điêu trị Bảng 5: Độc tính gây trì hoãn và ngưng điều trị

\begin{tabular}{|c|c|c|}
\hline Độc tính & $\begin{array}{c}\text { Số bệnh } \\
\text { Nhần }(\mathbf{N})\end{array}$ & $\begin{array}{c}\text { Tỷ lệ } \\
\mathbf{( \% )}\end{array}$ \\
\hline Giảm bạch cầu trung tính & 4 & 7,8 \\
\hline Giảm huyết sắc tố & 3 & 5,9 \\
\hline Giảm tiếu câuu & 1 & 2,0 \\
\hline Tăng AST/ALT & 1 & 2,0 \\
\hline Thần kinh ngoại vi & 1 & 2,0 \\
\hline Đau xương khớp & 1 & 2,0 \\
\hline
\end{tabular}


Nhận xét: Tỷ lệ bệnh nhân phải trì hoãn và ngưng điều trị chiếm tỳ lệ thấp, chủ yếu do độc tính trên hệ tạo huyết là giảm bạch câu trung tính $7,8 \%$ và giảm huyết sắc tố $5,9 \%$. Không ghi nhận trường hợp nào tử vong liên quan đến độc tính.

\section{BÀN LUÂ̂N}

1. Đặc điểm lâm sàng cận lâm sang. Nghiên cứu của chúng tôi tiến hành trên bệnh nhân cao tuổi tại bệnh viện Hữu Nghị, do đó tất cả bệnh nhân đều trên 60 tuổi. Nhóm tuổi $60-70$ chiếm tỷ lệ cao nhất là $64,7 \%$, nhóm tuổi $>70$ chiếm 35,3\%, bệnh nhân lớn tuổi nhất 77 tuổi. Trong đó nam giới chiếm $84,3 \%$, tỷ lệ nam/nữ là $5,4 / 1$. Nhóm tuổi $>70$ và tỷ lệ nam/nữ này cao hơn so với tác giả Trương Thị Kiều Oanh (2017) tuổi > 70 chiếm 15,9\%, tỷ lể nam/nữ 2,9/1[3], nhưng thấp hơn so với tác giả nước ngoài Biesma (2011) tuổi trung vị là 74, có cả nhóm bệnh nhân trên 80 tuổi[5]. Sự khác biệt này do tính chất của bệnh viện điều trị có chức năng chăm sóc cho các đối tượng cán bộ hưu, chủ yếu là nam giới, mặt bằng tuổi trung bình cao hơn các nơi khác. Trong nghiên cứu của chúng tôi, số bệnh nhân có bệnh kèm theo chiếm $37,3 \%$, tỷ lệ hút thuốc chiếm tỷ lệ cao $62,7 \%$, tỷ lệ bệnh nhân giai đoạn IVB cao hơn IVA là $56,9 \%$ so với $43,1 \%$, mô bệnh học chủ yễu là biểu mô tuyến chiếm $70,6 \%$, còn lại là biểu mô vảy $27,4 \%$ và biểu mô tế bào lớn 2,0\%.

Liều điều trị so với liều chuẩn ở nhóm bênh nhân dùng liêuu $\geq 85 \%$ chiếm tỷ lệ $80,4 \%$, nhóm bệnh nhân dùng liều < 85\% chiếm tỷ lệ 19,6\%. Kết quả này tương tự với tác giả Trương Thị Kiều Oanh (2017) số bệnh nhân dùng liều $\geq 85 \%$ chiếm tỷ lệ $77,8 \%[3]$, tuy các bệnh nhân trong nghiên cứu cao tuổi, nhưng đa số có thể trạng tốt nên có thể dùng được đủ liểu để đạt được kết quả điều trị tối ưu.

\section{Tác dụng không mong muốn}

2.1 Độc tính trên hệ tạo huyết. Độc tính trên hệ tạo huyết là độc tính được quan tâm nhất khi điều trị hóa chất. Nghiên cứu của chúng tôi ghi nhận tỷ lệ giảm bạch câuulà $25,5 \%$, giảm bạch câu trung tính là $37,3 \%$, giảm huyết sắc tố là $29,4 \%$ và giảm tiểu cầu là $13,7 \%$. Tuy vậy phần lớn độc tính ở mức độ độ 1 và 2 . Số bệnh nhân có độc tính nghiêm trọng (độ 3 và 4) có tỷ lệ thấp: giảm bạch cầu độ 3 là $5,9 \%$, không có độ 4; giảm bạch cầu trung tính độ 3 là7,8\%, độ 4 là 2,0\%; không có trường hợp nào giảm huyết sắc tố và giảm tiểu cầu độ 3,4 .

Kết quả của chúng tôi tương đồng với kết quả của tác giả Trương Thị Kiều Oanh (2017) khi nghiên cứu 63 bệnh nhân cao tuổi cho thấy giảm bạch câuu là $20,6 \%$, giảm bạch câu trung tính là $38,1 \%$, giảm huyết sắc tố là $27 \%$, giảm tiểu câu $12,7 \%$ [3] và cũng tương đồng với kết quả của Biesma và cs (2011) giảm bạch câu $17 \%$, giảm bạch cầu hạt $33 \%$, giảm tiểu cầu $2 \%$ [5]. Một nghiên cứu khác trên bệnh nhân cao tuối lại cho kết quả cao hơn so với kết quả của chúng tôi. Theo Shenshawyvà cs (2012), tỷ lệ độc tính độ 3,4 ở bach cầu hat là $22,7 \%$; huyết sắc tổ $9,1 \%$; tiểu cầu $4,5 \%$. Sự khác biệt này là do nghiên cứu trên dùng liều Paclitaxel và Carboplatin cao hơn nghiên cứu của chúng tôi, Paclitaxel 200mg/m² kết hợp Carboplatin AUC 6 [6].

2.2 Độc tính trên chức năng gan, thận, tiêu hóa. Nghiên cứu của chúng tôi ghi nhận độc tính tăng men gan AST/ALT là $13,7 \%$; buồn nôn $19,6 \%$; nôn $9,8 \%$; tiêu chảy $11,8 \%$ và các độc tính này đều ở độ 1,2 . Trong đó có 1 bệnh nhân tăng Creatinin máu độ 1 chiếm 2,0\%, là trường hợp bệnh nhân có tiêu chảy, nhưng Creatinin về bình thường sau truyền bù dịch điện giải.

Kết quả này cũng tương tự như tác giả Trương Thị Kiều Oanh (2017) tỷ lệ tăng men gan là $12,7 \%$; buồn nôn $14,3 \%$; nôn $9,5 \%$; ỉa chảy $12,7 \%$ đều ở độ 1,2 [3]. Theo Shenshawyvà cs (2012) với liều hóa chất cao hơn,tỷ lệ nôn độ 3, 4 là $13,6 \%$, cao hơn so với kết quả của chúng tôi [6]. Trong nghiên cứu của chúng tôi tăng Creatin chiếm 2,0\% cao hơn các nghiên cứu trên, xuất hiện ở 1 bệnh nhân có tiêu chảy, do vậy cần chú ý bù đủ dịch điện giải đối với các bệnh nhân có tác dụng phụ tiêu chảy khi sử dụng phác đồ này.

2.3 Các độc tính khác. Độc tính thần kinh cảm giác ngoại vi trong nghiên cứu của chúng tôi có tỷ lệ $17,6 \%$ ở độ $1 / 2$, không có bệnh nhân nào độ $3 / 4$. Kết quả này tương tự các tác giả Trương Thị Kiều Oanh (2017) 15,9\%[3]và Biesma (2011) 15\% [5]. Nhưng thấp hơn so với Shenshawyvà cs (2012) khi sử dụng liều hóa chất cao hơn, tỷ lệ rối loạn thần kinh cảm giác ngoại vi độ 3, 4 là 22,7\% [6]

Độc tính đau xương khớp chiếm tỷ lệ $21,6 \%$, đều ở mức độ $1 / 2$ và được khắc phục bằng thuốc giảm đau thông thường. Tất cả bệnh nhân trong nghiên cứu đều rụng tóc sau hóa trị, với $41,2 \%$ độ 3 và $58,8 \%$ độ 4 . Kết quả này tương tự với tác giả Nguyễn Trọng Hiếu (2012) tỷ lệ đau xương khớp 25\%; tỷ lệ rụng tóc độ $3 / 4$ là 100\% [2].

2.3 Độc tính gây trì hoãn và ngưng điêu trị. Tỷ lệ bệnh nhân phải trì hoãn và ngưng điều trị chiếm tỷ lệ thấp, chủ yếu do độc tính trên hệ tạo huyết là giảm bạch cầu trung tính $7,8 \%$ và giảm huyết sắc tố $5,9 \%$. Trong đó có 2 bệnh 
nhân $(3,9 \%)$ xuất hiện giảm bạch cầu trung tính độ 3 và giảm huyết sắc tố độ 2 phải trì hoãn điều trị 1 tuần, 1 bệnh nhân $(2 \%)$ giảm bạch cầu trung tính độ 4 và giảm huyết sắc tố độ 2 ngưng điêu trị sau 3 chu kỳ, 1 bệnh nhân ( $2 \%$ ) giảm bạch cầu trung tínhđộ 3 và giảm tiểu cầu độ 2 ngưng điêu trị sau 4 chu kỳ.

Tỳ lệ trì hoãn điều trị do độc tính tăng AST/ALT là $2 \%$, thần kinh cảm giác ngoại vi là $2 \%$, đau xương khớp là $2 \%$. Các bệnh nhẩn điều phải trì hoãn 1-2 tuần điều trị. Trong nghiên cứu của chúng tôi không ghi nhận trường hợp nào tử vong liên quan đến độc tính.

\section{KẾT LUẬN}

Các độc tính trên hê tạo huyết bao gồm: tỷ lệ giảm $\mathrm{BC}, \mathrm{BCTT}$ là $25,5 \% ; 37,3 \%$, trong đó chủ yếu là giảm $B C$ và giảm $B C T$ độ $1 / 2$ là $19,6 \%$ và $27,4 \%$. Tỷ lệ giảm HST, giảm tiểu câu là $29,4 \%$ và $13,7 \%$, đều ở độ $1 / 2$. Độc tính trên gan, thận, tiêu hóa bao gồm: tỷ lệ tăng AST/ALT và tăng Creatinin là $13,7 \%$ và $2,0 \%$, tỷ lệbuồn nôn, nôn là $19,6 \%$ và $9,8 \%$, tiêu chảy là $11,8 \%$, đều ở độ $1 / 2$. Tỷ lệ rối loạn thần kinh cảm giác ngoaai vi, đau xương khớp là $17,6 \%$ và $21,6 \%$, ở độ $1 / 2$. Rụng tóc gặp ở tất cả các bệnh nhân sau hóa trị. Tỷ lệ trì hoã̃n và ngưng điều trị thấp, chủ yếu do giảm $B C T T$ là $7,8 \%$ và giảm HST là $5,9 \%$. Không có trường hợp nào tử vong liên quan đến độc tính. Các độc tính ghi nhận trong nghiên cứu đều chấp nhận được và an toàn để điêu trị cho bệnh nhân cao tuổi.

\section{TÀI LIẸU THAM KHẢO}

\section{Lê Tuấn Anh, Nguyễn Ngọc Bảo Hoàng} (2013). Đặc điểm lâm sàng và điều trị của 1158 bệnh ñhân ung thư phổi tại Trung tâm Ung bướu Chợ Rẫ̂y. Y học thực hành, 8(8), 7869.

2. Nguyến Trọng Hiếu (2012), Đánh giá hiệu quả và độc tính phác đồ Paclitaxelnano/Carboplatin trong ung thư phổi không tế bào nhỏ giai đoạn IIB-IV, Luận văn thạc sỹ y học, Đại học Y Hà Nội.

3. Trương Thi Kiêu Oanh (2017), Đánh giá đáp ứng hóa chẩt phác đồ Paclitaxel-Carboplatin bước 1 ở bệnh nhân ung thư phổi không tế bào nhỏ giai đoạn IIIB-IV trên 60 tuổi, Luận án thạc sỹ y học, Đại học Y Hà Nội.

4. Bray F, Ferlay J et al (2018). Global cancer statistics 2018: GLOBOCAN estimates of incidence and mortality worldwide for 36 cancers in 185 countries, CA Cancer J Clin, 2018 Nov, 68(6), 394-424.

5. B. Biesma, A. N. M. Wymenga, A. Vincent et al (2011). Quality of life, geriatric assessment and survival in elderly patients with non-small-cell lung cancer treated with carboplatin-gemcitabine or carboplatin-paclitaxel: NVALT-3 a phase III study. Annals of Oncology, 22, 1520-1527.

6. Hala Mohamed El-Shenshawy, Saleh Taema, Eman El-Zahaf et al (2012). Advanced non-smal cell lung cancer in elderly patients : The standard every 3-weeks versus weekly paclitaxel with carboplatin. Egyptian Journal of Chest Diseases and Tuberculosis, 61, $485-493$.

7. Junya Zhu, Dhruv B. Sharma, Aileen B. Chen, et al(2013). Comparative Effectiveness of Three Platinum - Doublet Chemotherapy Regimens in Elderly Patients With Advanced Non-Small Cell Lung Cancer. Cancer, 119, 2048-2060.

\section{NGHIÊN CỨU RỐI LOAN LIPID MÁU Ở NGƯờI CAO TUỔI TĂNG HUYẾT ÁP}

\begin{abstract}
TÓM TẮT.
Mục tiêu: Khảo sát tỷ lệ rối loạn lipid máu và mối liên quan giữa rối loạn lipid máu với một số chỉ số lâm sàng, cận lâm sàng ở người cao tuổi tăng huyết áp điêu trị tại Bệnh viện đa khoa 115 - Nghệ An. Phương pháp nghiển cứu: Nghiên cứu mô tả cắt ngang được thực hiện trên 150 bệnh nhân tăng huyết áp nguyên phát điều trị tại Bệnh viện đa khoa 115 Nghệ An. Kết quả: (1) Tỵ lệ rối loạn lipid máu ở bênh nhân cao tuổi tăng huyết áp là 88,0\% \% (2) Có mối liêên quan giữa rối loạn lipid máu với tình trạng gan nhiễm
\end{abstract}

\footnotetext{
${ }^{1}$ Trường Đại họ Y khoa Vinh

Chịu trách nhiệm chính: Nguyễn Văn Tuấn

Email: tuanminh1975@gmail.com

Ngày nhận bài: 9.8.2021

Ngày phản biện khoa học: 5.10.2021

Ngày duyệt bài: 13.10.2021
}

\section{Nguyễn Văn Tuấn ${ }^{1}$, Hoàng Thị Cúc ${ }^{1}$}

mõ, chỉ số BMI, chỉ số vòng bụng, thời gian phát hiện tăng huyết áp, uống nhiêuu rượu và ít vận động thể lực; (3) Chưa thấy mối liên quan giữa rối loạn lipid máu với nhóm tuổi (nhóm bệnh nhân $\geq 70$ tuổi so với nhóm bệnh nhân 60 - 69 tuổi), giới, tiền sử gia đình bị rối loạn lipid máu. Kết luận: Rối loạn lipid máu chiếm tỷ lệ rất cao ở bệnh nhân cao tuổi tăng huyết áp, đặc biệt ở những bệnh nhân có các yếu tố nguy cơ tim mạch khác đi kèm như thừa cân, béo phì, uống nhiều rượu và ít vận động thể lực.

Tư khóa: Rối loạn lipid máu, người cao tuổi, tăng huyết áp

\section{SUMMARY \\ DYSLIPIDEMIA IN ELDERLY PATIENTS WITH HYPERTENSION}

Objectives: To survey the prevalence of dyslipidemia and the relationship between dyslipidemia and some clinical and subclinical indexs 